\title{
Determination of reduced sulfur compounds by high-performance liquid chromatography in hydrothermal seawater and body fluids from Riftia pachyptila
}

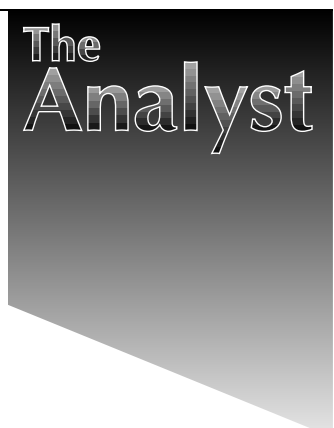

Cécile Gru, ${ }^{a}$ Pierre-Marie Sarradin, ${ }^{*} b$ Hélène Legoff, ${ }^{a}$ Sandrine Narcon, ${ }^{a}$ Jean-Claude Caprais $^{b}$ and François H. Lallier ${ }^{c}$

a ENSCR, Avenue du Général Leclerc, Rennes Beaulieu, 35700, France

b IFREMER BREST, DRO/EP, BP 70, Plouzane, F-29280, France

${ }^{c}$ Equipe Ecophysiologie, Observatoire Océanologique de Roscoff, UPMC-CNRS-INSU, Station

Biologique, 29682 Roscoff Cedex, BP 74, France

This paper describes a method for the determination of reduced sulfur compounds in hydrothermal seawater and body fluids from the hydrothermal tube worm Riftia pachyptila. Sulfur is a key component of the hydrothermal ecosystem based on chemosynthesis. Sulfur compounds were derivatized at $\mathrm{pH} 8$ (4.3 for sulfide in biological fluid) with a fluorescent reagent, monobromobimane, and separated by reverse-phase HPLC. The eluted compounds were detected by spectrofluorimetry. This method allowed the quantitative analysis of sulfide, sulfite, thiosulfate, cysteine and glutathione in seawater, vascular blood and coelomic fluids from $R$. pachyptila. The detection limits were in the $0.1 \mu \mathrm{mol} \mathrm{l}^{-1}$ range with a precision lower than $10 \%$. The method has been applied to hydrothermal seawater. The organisms are distributed along a gradient of sulfide (produced by the vent) and thiosulfate. Analysis of biological fluid was performed with a new sample treatment allowing the analysis of total sulfide (free and bound to haemoglobin) with results comparable to published methods.

Keywords: Sulfide; sulfite; thiosulfate; cysteine; glutathione; hydrothermal seawater; Riftia pachyptila, biological fluids

Deep sea hydrothermal vents are characterised by a set of unique environmental parameters. The chemical interactions between the magma source and the surrounding seawater produce strongly reducing hot waters enriched in methane and hydrogen sulfide, among others, and depleted in magnesium and oxygen. ${ }^{1-3}$ In the absence of light, the hydrothermal food chain is based on chemoautotrophic bacteria which derive the energy necessary for the fixation of inorganic carbon from the reduced sulfur compounds present in the vent fluid and the oxygen present in deep-sea water. Moreover, the most abundant invertebrate species, e.g., tubeworms, mussels and clams, ${ }^{4}$ are actually symbiotic associations with such chemoautotrophic bacteria.

The hydrothermal vent vestimentiferan Riftia pachyptila probably represents the most achieved and studied example of this kind of symbiosis. ${ }^{4,5}$ This worm is devoid of digestive tract and houses in an internal organ, the trophosome, abundant sulfur oxidising bacteria which are completely dependent on their host for their supply of inorganic compounds. Therefore, the host has evolved a specific mechanism to ensure proper acquisition and transport of $\mathrm{H}_{2} \mathrm{~S}, \mathrm{O}_{2}$ and $\mathrm{CO}_{2}$. Acquisition of $\mathrm{O}_{2}$ and $\mathrm{CO}_{2}$ from the water occurs mainly through a diffusion process across the branchial plume, while sulfide apparently requires an ionic transport of $\mathrm{HS}^{-6,7}$ yet to be characterised. Transport of $\mathrm{O}_{2}$ and $\mathrm{H}_{2} \mathrm{~S}$ is achieved bound to the proteins on different $\operatorname{sites}^{8-10}$ of the circulating haemoglobin, ${ }^{8}$ while $\mathrm{CO}_{2}$ is mainly transported as bicarbonate dissolved in the body fluids. ${ }^{11}$ On the other hand, the metabolic activity of the bacteria produces sulfate and protons which are either accumulated or excreted by the host. Evidence of active proton excretion exists 6,7 but nothing is known about the fate of sulfate.

Knowledge of the concentrations of the different sulfur compounds in the environment and in the biological fluids are a first and necessary step towards the elucidation of these processes. This work presents the adaptation of an analytical method published by Vetter et al. ${ }^{12}$ and Fahey et al. ${ }^{13}$ to analyse different sulfur components by reverse-phase HPLC after derivatization with monobromobimane. The study has been focused on the following compounds: $\mathrm{HS}^{-}$(sulfide, or $\mathrm{H}_{2} \mathrm{~S}$ ), $\mathrm{SO}_{3}{ }^{2-}$ (sulfite), $\mathrm{S}_{2} \mathrm{O}_{3}{ }^{2-}$ (thiosulfate), methanethiol, cysteine and glutathione. Polythionates and polysulfides have not been studied yet. The development was performed on the following matrices: hydrothermal seawater, vascular blood and coelomic fluid from the hydrothermal vent worm $R$. pachyptila.

\section{Experimental}

To measure sulfur compounds in biological and seawater samples, the protocol should allow the fixation of the different sulfur components to stop their reaction during the preparation and should also separate as many sulfur compounds as possible during a single assay. The principle of the method is based on the use of monobromobimane $(\mathrm{mBBr})$, a fluorescent agent, which reacts selectively with thiols and reduced sulfur compounds to produce highly fluorescent derivatives as illustrated in reaction (1). These fluorescent derivatives can then be separated by reverse-phase HPLC.

$$
\mathrm{RSH}+\mathrm{mBBr} \rightarrow \mathrm{mBSR}+\mathrm{HBr}
$$

The sulfur compounds detected through such a method are therefore: sulfite, cysteine, thiosulfate, glutathione, methanethiol and sulfide. Sulfate cannot be analysed by this method but can be quantified by ionic chromatography (work under progress).

\section{Solutions}

The stock standard solutions $\left(\mathrm{SO}_{3}{ }^{2-}, \mathrm{S}_{2} \mathrm{O}_{3}{ }^{2-}\right.$, methanethiol, cysteine and glutathione) were prepared at a concentration of 20 mmol $1^{-1}$. Degassed water or seawater was prepared daily by ultrasonication under vacuum during $5 \mathrm{~min}$. Sodium thiosulfate pentahydrate (Merck, Darmstadt, Germany; pro analysi) and anhydrous sodium sulfite (Merck) solutions were prepared in degassed water, cysteine (Aldrich, Steinheim, Germany; 97\%) and glutathione (Aldrich, 98\%) in a v/v mixture $90+10$ wateracetonitrile (Panreac, Barcelona, Spain: HPLC gradient). The stock sulfide solution (about $50 \mathrm{mmol}^{-1}$ ) was prepared by 
dissolving rinsed $\mathrm{Na}_{2} \mathrm{~S} \cdot 9 \mathrm{H}_{2} \mathrm{O}$ crystals (Prolabo, Paris, France; rectapur) in degassed $\mathrm{H}_{2} \mathrm{O}$. This solution was periodically standardised following the procedure described in Grasshoff. ${ }^{14}$ Stock standard solutions were stable for ten days under $\mathrm{He}$ at $+4{ }^{\circ} \mathrm{C} ;-18{ }^{\circ} \mathrm{C}$ for cysteine. Working standard solutions were prepared every day in degassed water or degassed seawater. The thiolyte reagent was obtained from Calbiochem (Los Angeles, CA, USA) and prepared at $20 \mathrm{mmol}^{-1}$ in acetonitrile (Panreac, HPLC gradient). This solution was kept frozen and was stable for one month. ${ }^{12}$ The mobile phase was obtained with acetonitrile (Panreac, HPLC gradient) and ultrapure water (18 $\mathrm{M} \Omega$ ). The solvents were buffered with (per litre) a mixture of $4.916 \mathrm{~g}$ sodium perchlorate monohydrate (Panreac 99.5\%) and $2.5 \mathrm{ml}$ acetic acid (Panreac, HPLC gradient) and kept at constant temperature in a water bath during the analysis. The buffer solutions were prepared in $50 \mathrm{ml}$ ultrapure water as follows: $\mathrm{pH}$ 8, $0.596 \mathrm{~g}$ of HEPES (Sigma, St. Louis, MO, USA; H-7523), $0.093 \mathrm{~g}$ of EDTA (Sigma E-5134) and sodium

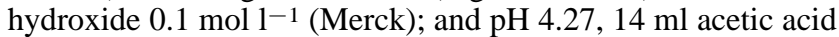
$0.2 \mathrm{~mol} \mathrm{l}^{-1}$ (Panreac, HPLC gradient), $6 \mathrm{ml}$ anhydrous sodium acetate $0.2 \mathrm{~mol} \mathrm{l}^{-1}$ (Sigma S-2889). The methane sulfonic acid (Sigma) was prepared at $25 \mathrm{mmol}^{-1}$ in water, this solution was kept for one month at ambient temperature in darkness. The 2-pyridyl disulfide solution (PDS; Aldrich 99\%) was prepared at $20 \mathrm{mmol}^{-1}$ in acetonitrile and was stable for one month at $+4{ }^{\circ} \mathrm{C}$. The water used in all experiments was ion exchanged UHQ (18 M $\Omega$, ELGA, Villeurbann, France).

\section{Apparatus}

The HPLC system comprised a Spectra-Physics Analytical Spectrasystem P2000 pump (San Jose, CA, USA) Spectra-
Physics Spectrasystem AS3000 autosampler (injected volume $10 \mu \mathrm{l}$ ), a guard column (Upchurch C135B; CIL), a reversephase column of Spherisorb $(250 \times 4.6 \mathrm{~mm}$; CIL S5 ODS2250A). The detector (spectrofluorimeter; Jasco FP 920) was connected to an integrator (Spectra-Physics Chromjet SP 4400). The excitation and emission wavelengths were, respectively, 390 and $480 \mathrm{~nm}$. The centrifuge was a Jouan A14.

\section{Procedures}

The different analytical procedures obtained after adaptation of the method to the analysis of seawater, biological fluids and sulfide in biological fluids are summarised in Table 1 for the elution gradients and in Fig. 1 for the sample treatment. All gradients were linear. A matrix effect was observed during the work on biological fluids causing an incomplete separation of the sulfide and blank peak. This poor resolution was overcome by modifying the elution gradient.

Table 1 Elution gradients used for the analysis of reduced sulfur compounds in seawater and biological fluids. The flow rate was $1 \mathrm{ml} \mathrm{min}-1$

$\begin{array}{lccc}\text { Sample } & \text { Time/min } & \text { Acetonitrile }(\%) & \text { Water (\%) } \\ \text { Seawater (A) } & 0 & 10 & 90 \\ & 10 & 30 & 70 \\ & 18 & 75 & 25 \\ \text { Biological fluid (B) } & 0 & 10 & 90 \\ & 10 & 30 & 70 \\ & 19 & 55 & 45 \\ & 21 & 40 & 60\end{array}$

SEAWATER ANALYSIS

\section{BIOLOGICAL FLUID ANALYSIS}

thiosulfate, cysteine \& glutathione

$100 \mu \mathrm{l}$ coelomic fluid or blood

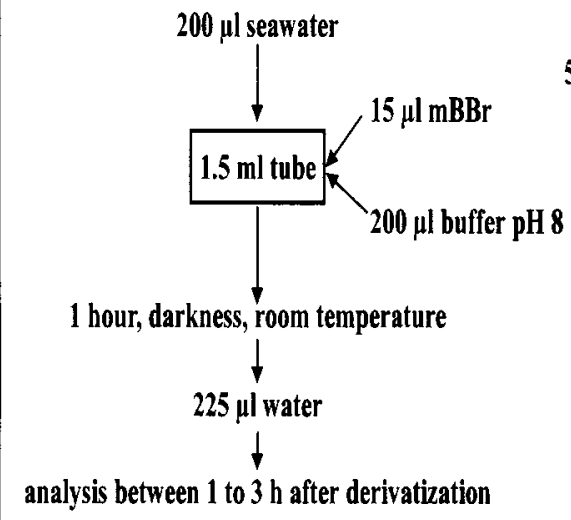

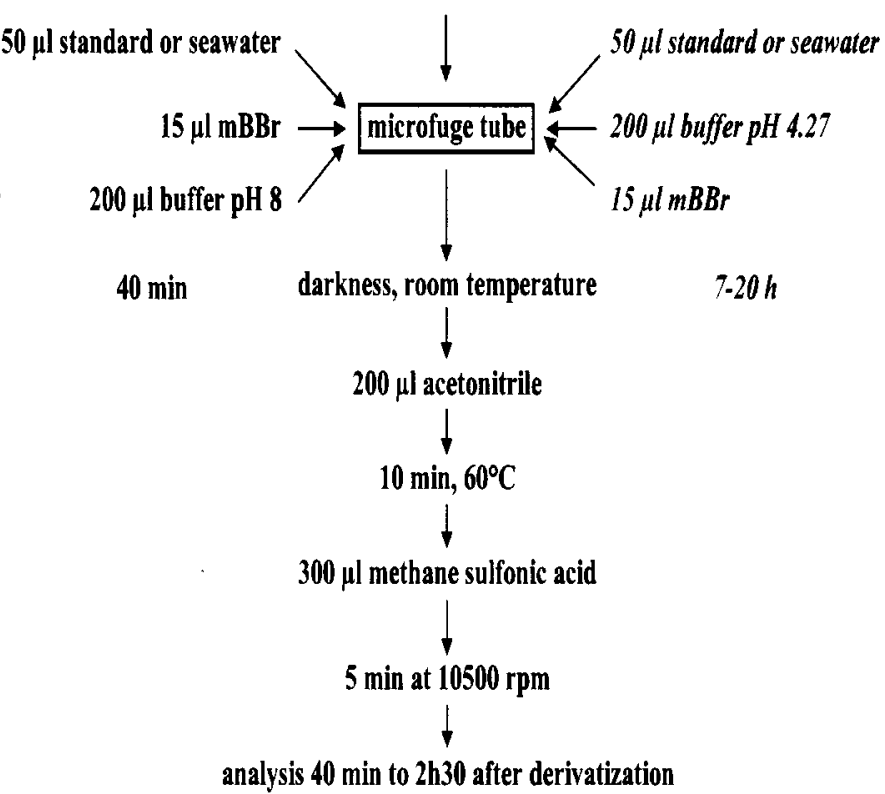

Fig. 1 Flow chart of analytical procedures for seawater and biological fluids analysis. 
The volume of reagent added was tested $(10,15$ and $25 \mu \mathrm{l})$ on a mixture of $1 \mathrm{mmol}^{-1}$ of reduced sulfur compounds. An addition of $15 \mu \mathrm{l}$ of the $20 \mathrm{mmol}^{-1}$ thiolyte reagent $(\mathrm{mBBr})$ was in sufficient excess to ensure the complete derivatization of 1 mmol $1^{-1}$ of reduced sulfur compounds. Larger volumes increased the reaction rate but also the cost of an analysis. The derivatization reaction is completed after $1 \mathrm{~h}$ for seawater (in 1.5 $\mathrm{ml}$ glass flask), $40 \mathrm{~min}$ for biological fluids (in $1.5 \mathrm{ml}$ microfuge tube) in darkness. The buffering of the solution at $\mathrm{pH} 8$ where the $\mathrm{RS}^{-}$form is predominant was necessary to have a faster reaction rate. The analysis of sulfide in biological fluid was the exception with a $\mathrm{pH}$ of 4.7-4.8 leading to a slower reaction rate $(6 \mathrm{~h})$. The adducts formed were stable for at least $20 \mathrm{~h}$. The acetonitrile precipitated the proteins present in the biological fluid while denaturation of the enzymes was obtained at $60{ }^{\circ} \mathrm{C}$ during $10 \mathrm{~min}$. The methanesulfonic acid stabilised the $\mathrm{mBBr}$ adducts and the precipitated proteins were removed by centrifugation. Each analysis should include a reagent blank to identify peaks arising from the reagents. A second blank was also prepared by reacting the reduced sulfur compounds and thiols present in the sample with PDS prior to derivatization. This reagent forms stable derivatives that will no longer react with bimane. This blank indicated any fluorescent non-sulfur component that may give a chromatographic peak unrelated to the bimane derivatization. ${ }^{12}$

\section{Sulfide analysis}

The haemoglobin of Riftia pachyptila functions as an oxygen and sulfide carrier. Sulfide is transported reversibly bound to the haemoglobin and is stabilised against spontaneous oxidation. $8,15,16$ Sulfide binding is strongly dependent on the $\mathrm{pH}$ as demonstrated by Childress et al. ${ }^{17}$ with a sulfide binding maximum at $\mathrm{pH} 8$ and a decrease of the bonding for higher and lower $\mathrm{pH}$. Working at $\mathrm{pH} 8$ implies analysing only the unbound sulfide, the sulfide added during the calibration being possibly bound to the remaining free sites giving erroneous results.

To analyse total sulfide, it is therefore necessary to preliminarily release the fraction bound to the haemoglobin by decreasing the $\mathrm{pH}$ (see Fig. 2). The maximum peak area corresponding to the maximum amount of released sulfide was obtained for a $\mathrm{pH}$ between 4.5 and 5 . The working buffer was chosen at 4.3 leading to a $\mathrm{pH}$ measured in the sample of 4.8 . This decrease in $\mathrm{pH}$ in the reaction mixture caused a decrease in the derivatization rate. At $\mathrm{pH} 4.3$, the plateau was attained for a reaction time of $6 \mathrm{~h}$ and was stable up to $20 \mathrm{~h}$.

\section{Sampling and sample treatment}

Water sampling was done during the HOT 96 French American cruise $\left(9^{\circ}\right.$ and $13^{\circ} \mathrm{N}$ East Pacific Rise, February-March 1996) on the N/O Nadir hosting the submersible Nautile. Water sampling was made at several points including the smokers, the animal communities and the surrounding cold seawater. A new device conceived by Caprais and Sarradin ${ }^{18}$ based on evacuated Teflon coated bottles was used for the first time to collect fluid samples $(150 \mathrm{ml})$ in the vicinity of the animals. Titanium syringes $(750 \mathrm{ml})^{1,19}$ were used for the sampling of hot vent fluid.

Water samples were derivatized ( $200 \mu \mathrm{l}$ water, $15 \mu 1 \mathrm{mBBr}$, $200 \mu \mathrm{l}$ buffer $\mathrm{pH} 8$ ) on board and stored at $-20^{\circ} \mathrm{C}$ until analysis.

Biological samples used in this study came from various cruises (HERO 91 and HERO 92) on the East Pacific Rise (9 and $\left.13^{\circ} \mathrm{N}\right)$. Biological fluids were sampled on board from animals recovered from the bottom by the submersible, kept frozen $\left(-80^{\circ} \mathrm{C}\right)$ immediately after sampling, derivatized and analysed later in a shore-based laboratory.

\section{Results and discussion}

\section{Performance of the method}

The working range was $1 \mathrm{mmol}^{-1}$ total sulfur compounds. The linearity for each compound has been verified up to 800 $\mu \mathrm{mol} 1^{-1}$ on two ranges: $0-150$ and $150-800 \mu$ mol $1^{-1}$ by plotting calibration curves for each compound (duplicate injections of $0,50,100,150,200,400$ and $800 \mu \mathrm{mol}^{-1}$ in water) and following the method presented by $\operatorname{Huber}^{20}$ (at \pm $5 \%$ ). Performances of the method are presented in Table 2 . The chromatograms obtained are shown in Fig. 3.

\section{Quantitative analysis}

Daily calibration in seawater was performed using two standard mixtures $\left(0,50,100,150 \mu_{m o l} 1^{-1}\right)$ : a standard mixture containing sulfite, cysteine, thiosulfate and glutathione on the one hand, a standard solution of sulfide on the other hand (sulfide is very unstable and is rapidly oxidised into thiosulfate and sulfite). This method using linear fitted calibration curves gave equivalent results within the \pm reproducibility range and is less time and sample consuming than the standard addition method for the analysis of seawater and biological fluids. The

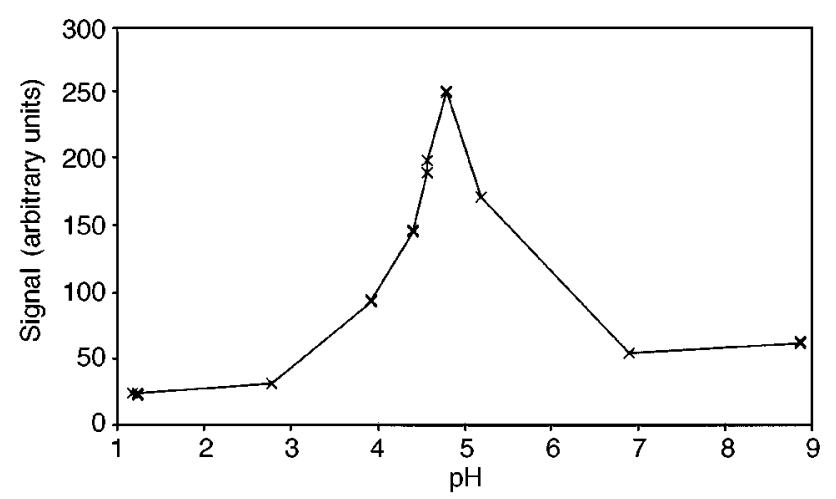

Fig. 2 Influence of the $\mathrm{pH}$ on the sulfide released from the haemoglobin in coelomic fluid. The $y$ axis represents the area of the sulfide peak obtained.

Table 2 Performance of the method in seawater and in coelomic fluid

\begin{tabular}{|c|c|c|c|c|c|c|c|c|c|}
\hline \multirow[b]{2}{*}{ Parameter } & \multicolumn{5}{|c|}{ Seawater } & \multicolumn{4}{|c|}{ Coelomic fluid } \\
\hline & $\mathrm{SO}_{3} 2-$ & Cys & $\mathrm{S}_{2} \mathrm{O}_{3}{ }^{2-}$ & Glu & $\mathrm{HS}^{-}$ & Cys & $\mathrm{S}_{2} \mathrm{O}_{3}^{2-}$ & Glu & $\mathrm{HS}^{-}$ \\
\hline D.L./ $/ \mu \mathrm{mol} 1^{-1 *}$ & 0.03 & 0.7 & 0.03 & 0.01 & 0.4 & $\dagger$ & $\dagger$ & $\dagger$ & $\dagger$ \\
\hline Reproducibility $(\%)^{\S}$ & 4.6 & 9.1 & 3.5 & 3.3 & 4.7 & 8.1 & 4.4 & 7.2 & 5.0 \\
\hline$R_{\mathrm{t}} / \mathrm{min}$ & 3.3 & 5.2 & 5.6 & 6.7 & 14.9 & 5.0 & 5.8 & 8.3 & 19.7 \\
\hline
\end{tabular}

* D.L., detection limit, IUPAC norm $(3 \times$ standard deviation of 20 blanks $\times$ slope of the standard curve). + Sulfur compounds were present in the working matrix; the determination of the detection limit was therefore not possible. $¥$ Repeatability, five injections of the same standard $\left(100 \mu\right.$ mol $\left.1^{-1}\right)$ by the same operator in the same conditions. $\$$ Reproducibility, injections of five identical standards $\left(100 \mu \mathrm{mol} 1^{-1}\right)$ by the same operator in the same conditions. 
quantitative analysis of sulfide in biological fluids requires the standard additions method.

\section{Sulfite in biological fluids}

Fig. 4 shows a typical curve obtained after a standard addition procedure of sulfite in coelomic fluid. The peak areas increase only after an addition of 50 to $100 \mu \mathrm{mol}^{-1}$. Sulfites are
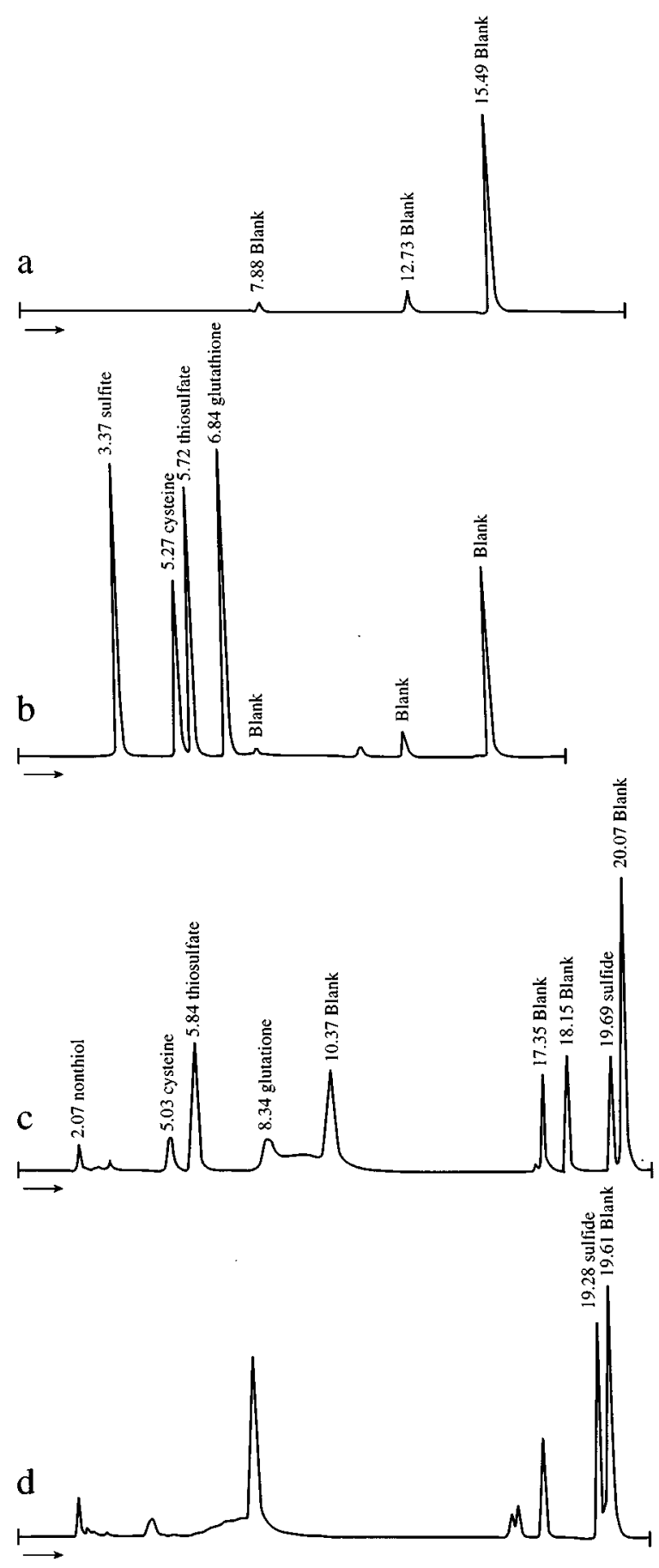

Fig. 3 (a) Chromatogram of a reagent blank, elution gradient A, $1 \mathrm{ml}$ $\mathrm{min}^{-1}$; (b) chromatogram of a $100 \mu \mathrm{mol} 1^{-1}$ standard mixture (sulfite, cysteine, thiosulfate, glutathione) in seawater, elution gradient A, $1 \mathrm{ml}$ $\mathrm{min}^{-1}$; (c) chromatogram of coelomic fluid spiked with a $50 \mu \mathrm{mol} 1^{-1}$ standard mixture (cysteine, thiosulfate, glutathione), elution gradient B, 1 $\mathrm{ml} \mathrm{min}{ }^{-1}$; (d) Chromatogram of coelomic fluid spiked with $50 \mu \mathrm{mol} \mathrm{1}^{-1}$

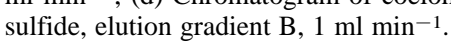

unstable sulfur compounds and can react with the oxygen present in the biological fluids at $\approx 2 \mathrm{mmol}^{-1}$ in haemoglobincontaining air saturated coelomic fluid; $3.5 \mathrm{mmol}^{-1}$ in blood.

\section{Storage after derivatization}

After centrifugation, the samples were frozen at $-18{ }^{\circ} \mathrm{C}$ until analysis. A study on frozen samples spiked with $50 \mu \mathrm{mol} 1^{-1}$ of cysteine, thiosulfate and glutathione and $25 \mu \mathrm{mol} 1^{-1}$ of sulfide does not result in any loss of analyte within the \pm reproducibility range after two months. This result is also stated in Vetter et al. ${ }^{12}$ who found no significant loss after up to 20 months.

\section{Applications}

\section{Seawater}

Seawater sampled during the HOT96 cruise around the vent organisms was analysed. The results obtained are presented in Table 3 and highlight the different concentration ranges observed for each biological community. The organisms are distributed along a gradient of sulfur compounds: sulfides are produced by the hydrothermal vent and the oxidised compounds appear during the dilution of the hydrothermal fluid by the surrounding seawater. Traces of cysteine and glutathione were observed in some samples among the organisms (0.1-1.3 $\mu \mathrm{mol} 1^{-1}$ ). These results will need to be compared with the concentrations in the biological fluids to find if the distribution of the organisms along the chemical (sulfide) gradient is a function of the sulfur compounds concentrations.

\section{Biological fluids}

The method was applied to several samples of Riftia pachyptila (blood and coelomic fluid) sampled during HERO 91 and HERO 92 on the East Pacific Rise $\left(9\right.$ and $\left.13^{\circ} \mathrm{N}\right)$. These values are indicative as the conservation method (frozen at $-80{ }^{\circ} \mathrm{C}$ just after sampling, derivatised and analysed on shore) had not been established. However, the ranges obtained are identical to those

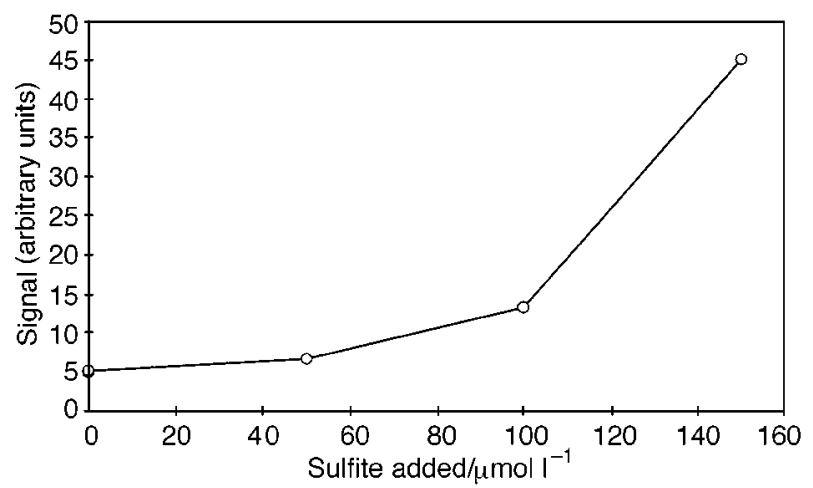

Fig. 4 Standard additions of sulfite in coelomic liquid.

Table 3 Analysis of sulfur compounds in water samples from the East Pacific Rise, 9 and $13^{\circ}$ N, HOT 96 cruise

$\begin{array}{lccc}\text { Sample location } & \begin{array}{c}\text { Sulfite/ } \\ \mu \mathrm{mol} 1^{-1}\end{array} & \begin{array}{c}\text { Thiosulfate/ } \\ \mu \mathrm{mol} 1^{-1}\end{array} & \begin{array}{c}\text { Sulfide/ } \\ \mu \mathrm{mol} 1^{-1}\end{array} \\ \text { Vent } & 1.6 \pm 1 & 26 \pm 1 & 160 \pm 30 \\ \text { Among Alvinella spp. } & 2 \pm 2 & 14 \pm 7 & 66 \pm 105 \\ \text { Among Riftia pachyptila } & 1 \pm 1.6 & 7 \pm 9 & 24 \pm 37 \\ \text { Among mussels } & 0.2 \pm 0.3 & 1.6 \pm 2 & 1.3 \pm 1.2 \\ \text { Seawater } & >\text { D.L. } & 0.2 \pm 0.3 & >\text { D.L. } \\ { }^{*} \text { Analysed by colorimetry. } & & & \\ & & \end{array}$


Table 4 Concentrations of sulfur compounds in biological fluids of Riftia pachyptila

\begin{tabular}{|c|c|c|c|c|c|}
\hline \multicolumn{2}{|c|}{ Sample } & \multirow{2}{*}{$\begin{array}{c}\text { Sulfide/ } \\
\mu \mathrm{mol} \mathrm{1} 1^{-1} \\
32\end{array}$} & \multirow{2}{*}{$\begin{array}{c}\text { Thiosulfate/ } \\
\text { Mmol } 1^{-1} \\
8\end{array}$} & \multirow{2}{*}{$\begin{array}{l}\text { Cysteine/ } \\
\text { 4mol 1-1 } \\
\text { <D.L.* }\end{array}$} & \multirow{2}{*}{$\begin{array}{c}\text { Glutathione/ } \\
\text { umol 1-1 } \\
\text { <D.L. }\end{array}$} \\
\hline Coelomic fluid & Sample 6.6 & & & & \\
\hline & Sample 2.4 & 114 & 48 & 2 & 1 \\
\hline \multirow[t]{2}{*}{ Blood } & Sample 17.2 & 370 & 16 & 7 & <D.L. \\
\hline & Sample 17.4 & 338 & 124 & 5 & <D.L. \\
\hline Coelomic liquid & Childress et al. ${ }^{15}$ & $89 \pm 87$ & $13 \pm 17$ & na ${ }^{\dagger}$ & na \\
\hline Blood & & $714 \pm 332$ & $24 \pm 34$ & na & na \\
\hline
\end{tabular}

found by Childress et al. ${ }^{15}$ (see Table 4 ) and reflect the ability of the worm's haemoglobin to bind and transport high sulfide concentrations to its endosymbiont.

\section{Conclusion}

The method has been applied to the quantitative analysis of sulfur compounds in seawater, blood and coelomic liquid from $R$. pachyptila. The detection limits were in the $0.1 \mu \mathrm{mol} 1^{-1}$ range with a repeatability and reproducibility (precision) lower than $10 \%$. The new procedure allowed the analysis of the total sulfide concentrations in the biological fluids (free and bound to the haemoglobin) with results comparable to the few presented in the literature. The method has been applied to hydrothermal seawater and biological fluids. This work is a first step toward the study of the $\mathrm{S}$ cycle in the hydrothermal ecosystem. The following step will be the simultaneous sampling of organisms and surrounding seawater to determine the interactions of fluid and organisms. The method will later be applied to other biological organisms present in the hydrothermal ecosystem such as Alvinellids, mussels and crabs.

This work has been performed under the URM $n^{\circ} 7$ IFREMER frame. It has been partially granted by the national French program Dorsales and the TMR-LSF program of the DG XII of the European Union.

\section{References}

1 Von Damm, K. L., PhD Thesis, Massachusetts Institute of Technology and Woods Hole Oceanographic Institute, 1983.

2 Campbell, A. C., Palmer, M. R., Klinkhammer, G. P., Bowers, T. S., Edmond, J. M., Lawrence, J. R., Casey, J. F., Thompson, G., Humphris, S., Rona, P., and Karson, J. A., Nature, 1988, 335, 514.

3 Von Damm, K. L., in Seafloor Hydrothermal Systems. Physical, Chemical, Biological and Geological Interactions, ed. Humphris, S. E., Zierenberg, R. A., Mullineaux, L. S., and Thomson, R. E. American Geophysical Union, 1995, 222.
4 Childress, J. J., and Fisher, C. R., in Oceanogr. Mar. Biol. Annu. Rev., 1992, 30, 337.

5 Nelson, D. C., and Fischer, C. R., in Microbiology of Deep Sea Hydrothermal Vents, ed. Karl, D. M., CRC Press, Boca Raton, FL, 1995.

6 Goffredi, S. K., Childress, J. J., Desaulniers, N. T., Lee, R. W., Lallier, F. H., and Hammond, D., J. Exp. Biol., 1997, 200, 883.

7 Goffredi, S. K., Childress, J. J., Desaulniers, N. T., and Lallier, F. H., J. Exp. Biol., 1997, 200, 2609.

8 Arp, A. J., Childress, J. J., and Vetter, R. D., J. Exp. Biol., 1987, 128, 139.

9 Zal, F., Suzuki, T., Kawasaki, Y., Childress, J. J., Lallier, F. H., and Toulmond, A., Proteins, 1997, 29, 562.

10 Zal, F., Leize, E., Lallier, F. H., Toulmond, A., Van Dorsselaer, A., and Childress, J. J., Proc. Nat. Acad Sci., in the press.

11 Toulmond, A., Lallier, F. H., de Frescheville, J., Childress, J. J., Lee, R., and Sanders, N. K., Deep-Sea Res., 1994, 41, 1447.

12 Vetter, R. D., Matrai, P. A., Javor, B., and O'Brien, J., in Biogenic Sulfur in the Environment, ed. Saltzman, E. S., and Cooper, W. J., American Chemical Society, Washington, 1989.

13 Fahey, R. C., Dorian, R., Newton, G. L., and Utley, J., in Radioprotectors and Anticarcinogens, Academic Press, New York, 1983.

14 Grasshoff, K., Methods of Seawater Analysis, Verlag Chemie, Weinheim, 1983, p. 419.

15 Childress, J. J., Fisher, C. R., Favuzzi, J. A., Kochevar, R. E., Sanders, N. K., and Alayse, A. M., Biol. Bull., 1991, 180, 135.

16 Fisher, C. R., Childress, J. J., and Sanders, N. K., Symbiosis, 1988, 5, 229.

17 Childress, J. J., Arp, A. J., and Fisher, C. R., Mar. Biol., 1984, 83, 109.

18 Caprais, J. C., Sarradin, P. M., Lemoign, T., and Kerdoncuff, J., La Lettre Dorsales, 1996, no. 3/2, 15.

19 Charlou, J. L., and Donval, J. P., J. Geophys. Res., 1993, 98, 9625.

20 Huber, L., LC-GC Int., 1998, 11, 96.

21 Fonselius, S., in Methods of Sea-water Analysis, ed. Grasshof, K., Ehrhardt, M., and Kremling, K., Verlag Chemie, Weinheim, 1983, 73.

Paper 8/00032H

Received January 2, 1998

Accepted April 20, 1998 